\title{
Komparatystyka konstytucyjnoprawna Antecedencje, ewolucja, przewidywane kierunki rozwoju*
}

\section{Wprowadzenie \\ Istota problemu, przedmiot badań oraz kwestie terminologiczne}

Porównania są stałym i niezbędnym elementem naszego poznania, a komparatystyka jest nauką stosowaną od czasów starożytnych ${ }^{1}$, choć naukowe określenie metod komparatystyki prawnej jest sprawą stosunkowo nową ${ }^{2}$. Należąc do komparatystyki humanistycznej, najbardziej związała się ona $z$ elementami historycznej

* Ramy niniejszego opracowania nie pozwalają w wyczerpujący sposób zająć się całością problematyki komparatystyki konstytucyjnej. Poniżej przedstawiono jedynie zarys rozwoju dyscypliny, wraz z krótkim wprowadzeniem i wnioskami. Poza zakresem studium pozostaje m.in. analiza zagadnień metodologicznych, a także rozważania traktujące o specyficznych trudnościach dziedziny. Zamierzeniem autora było ukazanie ogólnego rozwoju dyscypliny (ujęcie historyczne) dla unaocznienia jej głębokich korzeni, specyfiki oraz znacznej zmienności.

1 W. Wagner, Comparative Law in The Modern World, The Review of Comparative Law 1988, Vol. 1, s. 45-46.

2 Stosowanie metod komparatystycznych równoznaczne było ze świadomością, że „mówimy prozą”. R.R. Ludwikowski, Prawo konstytucyjne porównawcze, Toruń 2000, s. 21-22. 
wiedzy o państwie i prawie ${ }^{3}$, chociaż studia konstytucyjnoporównawcze uznać można za rozważania filozoficzne ${ }^{4}$. W ujęciu modelowym komparatystyka prawna to dyscyplina, której istotę stanowi wartościujące porównywanie dwu lub więcej systemów prawa albo ich części w celu ustalenia tożsamości, różnic i podobieństw wraz ze wskazaniem ich przyczyn ${ }^{5}$.

Komparatystyka konstytucyjnoprawna związana jest w sposób szczególny z ustrojem państw, czyli całokształtem regulacji prawnej, której przedmiotem są instytucje i zasady porządku politycznego oraz społeczno-gospodarczego. Jeśli denotacja kategorii „konstytu-

3 Powiązanie komparatystyki prawa $z$ ujęciem historycznym jest silne: pierwsze próby porównywania miały być dokonywane w ramach historii powszechnej, która według Leibniza ipsam iurisprudentiae substantiam ingreditur miała wykryć wewnętrzna ideę rozwoju prawa wszystkich narodów. „Prawoznawstwo porównawcze było utożsamiane $z$ historią porównawczą prawa w jej uniwersalistycznym ujęciu”. K. Sójka-Zielińska, O stosowaniu metody porównawczej $w$ historii prawa, Państwo i Prawo 1963, nr 12, s. 838-839. Specyficzna dyscyplina „historia porównawcza prawa” pozwala na ukazanie ducha epoki oraz zespołu czynników warunkujących rozwój samego prawa, umożliwiając ocenę własnych zjawisk historycznych - M. Kuryłowicz, Prawa antyczne. Wykłady z historii najstarszych praw świata, Lublin 2006, s. 15. Jednym z osiągnięć ustrojowej komparatystyki historycznej było określenie źródeł podobieństw. J. Bardach, Metoda porównawcza $w$ historii państwa i prawa, Czasopismo PrawnoHistoryczne 1962, nr XIV, z. 2, s. 12, 16.

4 M. Tushnet, Comparative Constitutional Law, [w:] The Oxford Handbook of Comparative Law, red. M. Reimann, R. Zimmermann, Oxford-New York 2006, s. 1230-1232.

5 Zdaniem E. Gellnera kultury nie mogą być ocenianie jedynie przez pryzmat ich samych i pod kątem ich własnych standardów. Trzeba uznać istnienie pewnych niezmiennych mierników w tym zakresie. Inaczej żadne wypaczenia i zbrodnie nie będą mogły zostać potępione, korzystając z immunitetu bycia manifestacją kulturowej swoistości. E. Kośmicki, Globalizm a problem uniwersalizmu kulturowego, [w:] Współczesne problemy uniwersalizmu w Europie Środkowej $i$ Wschodniej, Warszawa 1996, s. 45. Wartościowanie to spełnianie podstawowego postulatu społecznego nauki. J. Wróblewski, Problemy metodologiczne badań instytucji prawno-ustrojowych, Problemy Rad Narodowych 1973, nr 25, s. 38-39. 
cja”6 i "prawo konstytucyjne"7 może zostać zdeterminowana, to próba zdefiniowania konstytucjonalizmu nie prowadzi do jednoznacznych wniosków ${ }^{8}$. Jakkolwiek wyrasta on $z$ prób przeciwstawienia się arbitralności władzy i ustabilizowania stosunków społecznych, nawiązując tym samym do klasycznego liberalizmu ${ }^{9}$, nie

6 Już w epoce Renesansu Grzegorz z Tours w dziele De Respublica przyjął constitutio za prawo o charakterze podstawowym - K.A. Wittfogel, Władza totalna, Toruń 2002, s. 124-125. Funkcjonuje wiele synonimów „konstytucji”, m.in. „ustawa zasadnicza”, „karta konstytucyjna” czy „ustawa rządowa”. To akt o specyficznym charakterze. B. Banaszak, Prawo konstytucyjne, Warszawa 2001, s. 54.; Prawo konstytucyjne, red. P. Tuleja, Warszawa 1997, s. 2-4; S. Sagan, Prawo konstytucyjne Rzeczypospolitej Polskiej, Warszawa 2001, s. 23-25.

7 Definiuje się tę gałąź poprzez charakter stosunków przez nią normowanych. Prawo konstytucyjne, red. Z. Witkowski, Torun 2002, s. 13-16. Według R. Davida fakt występowania państwa jako strony stosunku prawnego uzasadnia odmienność reguł, którym ten stosunek winien podlegać. S. Rozmaryn, Prawo francuskie $w$ aspekcie prawno-porównawczym, Państwo i Prawo 1960, nr 11, s. 767. Z kolei normy prawa konstytucyjnego regulują proces polityczny, rozumiany jako proces zaspokajania potrzeb społecznych. Prawo konstytucyjne, red. P. Sarnecki, Warszawa 1999, s. $1-4$.

8 U. Preuss, Current Challenges for the European Constitutional State: Supranational Integration, A Multicultural Europe and Globalization, [w:] Constitutional Cultures, red. M. Wyrzykowski, Warszawa 2000, s. 281. Z tej przyczyny problem analizuje się, raczej stawiając pytanie, z czym konstytucjonalizm się kojarzy. Ujęcie funkcjonalne sugeruje dokonanie w łonie społeczeństwa uzgodnienia w przedmiocie ochrony pewnych wartości, cementujące niekoniecznie demokratyczny porządek społeczny. W ujęciu strukturalnym podkreśla się aspekt historyczny konstytucjonalizmu, jego powiązanie $z$ procesem politycznym, który - podobnie jak demokracja stara się zrównoważyć władzę państwową z prawami jednostkowymi i kolektywnymi oraz z pierwszymi konstytucjami, których zadaniem była realizacja powyższego. R.R. Ludwikowski, op.cit., s. 39-40; V.I. Ganev, Constitiunalism and Civil Socjety in Post-Communist Eastern Europe, [w:] Constitutionalism in Transition: Africa and Eastern Europe, red. M.Ş. Rosen, Warszawa 2003, s. 304.

9 Związek liberalizmu $\mathrm{z}$ konstytucjonalizmem nie jest już tak oczywisty i bezpośredni jak onegdaj. Jeśli w ogóle należy odnosić się do koncepcji liberalnych zbliżonych do ujęcia J. Rawlesa, kładących nacisk nie tyle na pełną samorealizację jednostki, co na wolność rozumianą jako synteza jej 
może pomijać sytuacji świadomej koncentracji władzy czy wręcz „konstytucyjnego despotyzmu” ${ }^{10} . Z$ drugiej strony rozwój koncepcji państwa dobrobytu i zwiększanie funkcji oraz zadań realizowanych przez państwo stał w wyraźnej sprzeczności z koncepcją liberalną, a co za tym idzie nie do końca dawał się pogodzić $z$ pierwotnie ukształtowanym konstytucjonalizmem, zorientowanym na aspekt polityczny, a nie społeczny czy gospodarczy działalności państwa. $\mathrm{W}$ tym duchu formułuje się dwie definicje zagadnienia. Konstytucjonalizm sensu stricto to pogląd, że organizacja państwa i społeczeństwa winna zasadzać się na określonych normach i zasadach konstytucji. Konstytucjonalizm sensu largo obejmuje faktyczny porządek ustrojowy, określony zasadami i instytucjami wyrażonymi w konstytucji, jak i zespół funkcjonujących poglądów na temat funkcji i struktury konstytucji ${ }^{11}$.

praw i obowiązków. Chodzi więc zasadniczo o równość i tolerancję złożonych współczesnych społeczeństw. W. Sadurski, Liberalism and Constitutionalism, [w:] Constitutional Cultures, s. 137-142, 148-150; N. Dimitrijevic, Constitutionalism ans Privatized States, [w:] Constitutionalism in Transition, s. 240-250.

10 Warto zaznaczyć, że konstytucja o postanowieniach o określonej treści może stanowić zaprzeczenie konstytucjonalizmu. M. Tushnet, op.cit., s. 1231. B. Murungi, Voice in Discussion, [w:] Constitutionalism in Transition, s. 158. Istotą demokracji jest system złożonych instytucji, organizację których zapewnia nie tyle konstytucja, co konstytucjonalizm, stanowiąc niejako jej potwierdzenie. W. Osiatyński, Constitutionalism, Democracy, Constitutional Culture, [w:] Constitutional Cultures, s. 151-152.

11 Ujęcie sensu stricto adekwatne jest także dla epoki sprzed pojawienia się konstytucji w znaczeniu najwyższego aktu prawnego. To jednocześnie element szerszego znaczenia. M. Troper, Transformations of European Constitutional Culture, [w:] Constitutional Cultures, s. 11-12. Wąskie ujęcie pozostaje pod silnym wpływem coraz częstszych tendencji uniwersalistycznych: to suma współczesnych standardów. Zdaniem J. Habermasa studia konstytucyjnoporównawcze są tożsame ze studiami konstytucjonalizmu sensu stricto. W kontekście analiz systemów autokratycznych proponuje się wyraźne rozróżnienie na komparatystykę konstytucyjną, obejmującą wszystkie państwa $z$ aktem prawnym najwyższego rzędu, oraz komparatystykę konstytucjonalizmu, odnoszącą się tylko do państwa praworządnych. R. Henwood, Constitutional Culture in Africa?, [w:] Constitutional Cultures, s. 113-114, 
Relewantnym dla omawianego problemu zagadnieniem jest kategoria kultury konstytucyjnej. To stosunkowo nowe pojęcie, w związku z czym brak jego jednolitej definicji. Stanowi ona pole styku nauk politycznych, określających sposoby realizacji obranego celu, oraz kultury politycznej, koncentrującej się wokół relacji postawy społeczne a polityka i porządek prawny. Komponentem kultury konstytucyjnej jest konstytucjonalizm sensu stricto. Natomiast konstytucjonalizm rozumiany szeroko wyrasta z klimatu kulturowego, jednocześnie to środowisko kulturowe przekształcając ${ }^{12}$.

Z kolei kategorie „konstytucjonalizm porównawczy”, „porównawcza nauka prawa konstytucyjnego”, „komparatystyka konstytucyjna” („konstytucjonalna”) używane są wymiennie. Natomiast „legislacyjna komparatystyka konstytucyjna” czy „legislacja konstytucyjnoporównawcza” może być terminem określającym cel badań porównawczych, którym jest stworzenie nowych regulacji. W takim ujęciu prawo porównawcze nabiera wymiaru teoretycznego, a komparatystyka - raczej praktycznego ${ }^{13}$. Z kolei komparatystyka konstytucyjnoprawna w modelu „dynamicznym” koncentruje się na analizie kształtowania się konstytucji, a przyjęcie jako przedmiotu badania struktur konstytucyjnych przesądza o „statycznym” czy „strukturalnym” charakterze badań ${ }^{14}$.

Autor niniejszego studium opowiada się za terminami „komparatystyka prawa konstytucyjnego” jako nazwą dyscypliny badającej

121-122. Z kolei pojęcie „multikonstytucjonalizmu” należy postrzegać w trzech obszarach: przyszłości Unii Europejskiej, praw człowieka oraz prymatu prawa wspólnotowego. P. Tuleja, Podstawowe problemy zwiazane $z$ interpretacja Konstytucji RP w orzecznictwie TK, [w:] Księga XX-lecia orzecznictwa Trybunału Konstytucyjnego, Warszawa 2006, s. 226.

12 R.R. Ludwikowski, Constitiunal Culture of the new East-Central European Democracies, [w:] Constitutional Cultures, s. 55; R. Goldman, The Protection of Individual Rights as the Fundamental Element of the United States Constitutional Culture, [w:] ibidem, s. 25; Ch. Saunders, Constitiunal Culture in Transition, [w:] ibidem, s. 27-39; R. Henwood, op.cit., s. 107-108 .

13 R. Tokarczyk, Komparatystyka prawnicza, Kraków 2005, s. 27, 32.

14 R.R. Ludwikowski, Prawo konstytucyjne porównawcze, s. 14. 
normy, instytucje i całą gałąź prawa konstytucyjnego (wymiar jurydyczny) oraz „komparatystyka konstytucjonalizmu” jako nazwą badań, których przedmiotem jest nie tylko prawo, ale myśl czy też kultura konstytucyjna (wymiar jurydyczny wzbogacony doktrynalnym).

\section{Dzieje komparatystyki konstytucyjnoprawnej}

Platon w Prawach opisał greckie miasta-państwa, by zestawić je ze swoją wizją ustrojową ${ }^{15}$. Arystoteles w Ustroju politycznym Aten objął analizą prawnoporównawczą rozwiązania 158, a nawet - jak chcą niektórzy komentatorzy - 250 polis greckich ${ }^{16}$. Podobne założenie metodologiczne znajdziemy w Polityce ${ }^{17}$. W zachowanym fragmencie pracy Teofrasta $O$ prawach znaleźć można próbę określenia wspólnych zasad ustrojowych wszystkich polis. Jednocześnie autor wskazuje na różnice, skłaniając do ich eliminacji ${ }^{18}$. Powyższe dzieła stanowią nie tylko wybitne przejawy myśli politycznej, ale i wzór opartej na empirycznych podstawach komparatystyki polityczno-prawnej. $Z$ kolei pisarze rzymscy koncentrowali się wokół wykazywania wyższości własnych rozwiązań ustrojowych, określa-

15 Platon, Prawa, tłum. M. Makowska, Warszawa 1960.

16 Arystoteles, Ustrój polityczny Aten, tłum. L. Piotrowicz, Kraków 1973.

17 Zestawiał on systemy, poszukując modelu idealnego, „ponieważ te istniejące obecnie ustroje nie przedstawiają się zadawalająco”. Zastrzegł jednak, że ogranicza się tylko do państw „uchodzących za dobrze rządzone”, zawężając tym samym pole badawcze do porządków prawnych w miarę jednorodnych. Wydaje się wskazane podążać tym tropem - Arystoteles, Polityka, Warszawa 2004, s. 44. Prowadząc analizę rozwiązań ustrojowych i łącząc je razem w idealny jego zdaniem system, zdołał stworzyć przekonujący argument za ustanowieniem tradycji konstytucyjnej. M. Kikkeri, Comparative Legal Reasoning and European Law, Dordrecht-Boston-London 2001, s. 26.

18 R. Tokarczyk, op.cit., s. 49, 71-73. Koresponduje to ze współczesnym założeniem, że najpierw należy określić cechy wspólne, potem różnice. S. Rozmaryn, Z teorii badań i prac prawno-porównawczych, Państwo i Prawo 1966, nr 3, s. 401. 
jąc inne modele zawikłanymi i absurdalnymi ${ }^{19}$. Charakterystyczne jest, że treścią ich praktycznych koncepcji była realna rzeczywistość. Cechy państwa nie mogły zostać określone ze względu na brak możliwości porównania Imperium $z$ inną, zbliżoną pod względem poziomu organizacji i rozwoju jednostką geopolityczną ${ }^{20}$. Poza tym byłoby to sprzeczne $z$ polityką Rzymu, który pozostawiał podbitym ludom pozory samodzielności państwowej ${ }^{21}$.

Wieki średnie nie wniosły do dorobku badań porównawczych niczego oryginalnego. Stanowiło to bezpośredni skutek oparcia systemów politycznych na przodującym prawie rzymskim, a także faktu funkcjonowania wpływowych koncepcji uniwersalistycznych ${ }^{22}$. Następujący rozkład ośrodków władzy stanowi regres z punktu widzenia organizacji państwa, które musiało walczyć o byt, stawiając czoło kilku czynnikom ${ }^{23}$. $Z$ drugiej strony nowe rozwiązania ustrojowe „przynosił oręż”, więc zagadnienie wyboru porządku politycznego dokonanego na drodze wartościującego porównywania jawiło się przedmiotem jałowych analiz intelektualnych ${ }^{24}$.

19 Ciekawym wyjątkiem jest pochodzące $z$ III wieku n.e. Collatio Legum Mosaicarum et Romanorum, stanowiące porównanie prawa rzymskiego i mojżeszowego. R. Tokarczyk, op.cit., s. 49-50.

20 R. Kwiecień, Suwerenność państwa. Rekonstrukcja i znaczenie idei $w$ prawie międzynarodowym, Kraków 2004, s. 23-24.

21 A. Marszałek, Suwerenność a integracja europejska $w$ perspektywie historii. Spór o istotę suwerenności, Łódź 2000, s. 265.

22 Nieco inaczej rzecz przedstawiała się na Wyspach Brytyjskich. Fortescue, autor XV-wiecznych dzieł The Governance of England oraz De laudibus legum Angliae, podjął się dość subiektywnego porównania rozwiązań angielskich i francuskich, prowadzących do wniosków o wyższości modelu z Wysp. R. Tokarczyk, op.cit., s. 50.

23 Papiestwu, dążącemu do zaprowadzenia tzw. Pax Ecclesiastica (C. Berezowski, Prawo międzynarodowe publiczne, Warszawa 1966, s. 30; K. Łastawski, Historia Integracji Europejskiej, Toruń 2006, s. 18-20), Wschodniemu i Zachodniemu Cesarstwu (I. Popiuk-Rysińska, Suwerenność $w$ rozwoju stosunków międzynarodowych, Warszawa 1993, s. 19; K. Łastawski, op.cit., s. 21) oraz panom feudalnym (J. Jellinek, Ogólna nauka o państwie, Warszawa 1921, s. 300-301).

24 Przez wieki dominowało raczej narzucanie niźli dobrowolne przejmowanie obcych rozwiązań ustrojowych. Zdarzało się, że w wyniku przegranej 
Renesans, otwierający erę nowożytną, której cechą charakterystyczną jest dążenie do rozgraniczenia sfery doświadczenia i sfery spekulacji, stworzenie ściślejszego pojęcia nauki oraz przekonanie o czynnej naturze ludzkiego rozumu, zdolnego do poznawania całego świata ${ }^{25}$, to początek trwającego do dziś rozkwitu myśli komparatystycznej ${ }^{26}$. Wówczas uświadomiono sobie, że to, co „nasze”, wcale nie musi być lepsze od tego, co „obce”. Nie wydaje się pozbawione zasadności określić ów fenomen mianem kresu europocentryzmu. Szukano wówczas odpowiedzi na pytania postawione jeszcze w poprzedniej epoce ${ }^{27}$. Pisarze Renesansu starali się stworzyć pomost między polityką a historią: zadaniem dzieła politycznego nie jest moralizowanie i tworzenie utopijnych modeli ustrojowych $^{28}$. Dlatego też, dzięki wyzwoleniu wartości dojrzewających w wiekach średnich, rozpoczynają się poszukiwania nowych ustrojów ${ }^{29}$.

wojny, uznawanej za zwyczajny środek prowadzenia polityki, przegranym przychodziło żyć w systemie zorganizowanym przez zwycięzców. W. Wagner, op.cit., s. 45-46.

25 H. Izdebski, Historia myśli politycznej i prawnej, Warszawa 2001, s. 69 .

26 Do głównych „katalizatorów” rozwoju zalicza się odkrycia geograficzne i kontakty z nowymi, specyficznie zorganizowanymi społecznościami, ponowne zainteresowanie dziełami antycznymi, ruchy reformacyjne oraz powstanie nowej metodologii poznania. J. Justyński, Historia doktryn polityczno-prawnych, Torun 1997, s. 136; A.R. Nowicki, Wykłady z historii filozofii i myśli społecznej Odrodzenia, Warszawa 1956, s. 5; A. Sylwestrzak, Historia doktryn politycznych i prawnych, Warszawa 1994, s. 129.

27 Poszukując nowych rozwiązań, doktrynerzy nie do końca potrafili zerwać ze średniowiecznym postrzeganiem świata. „Pod wieloma względami Odrodzenie było [...] kryzysem poprzedniej epoki” - J. Justyński, op.cit., s. 135.

28 S. Opara, Studia z filozofii społecznej Renesansu i Odrodzenia, Warszawa 1985, s. 151.

29 G.L. Seidler, O istocie władzy państwowej, Kraków 1946, s. 130. 
Dzieła Machiavellego ${ }^{30}$, Bodina ${ }^{31}$, Grotiusa ${ }^{32}$ czy Hobbesa ${ }^{33}$ to traktaty, których autorzy $\mathrm{w}$ toku formułowania twierdzeń opisujących wizję idealnego ustroju powoływali się na zgromadzony materiał empiryczny. Innym przejawem myśli komparatystycznej były pisma utopistów, m.in. More'a ${ }^{34}$ i Campanelli ${ }^{35}$. $Z$ tej perspektywy w XVI i XVII wieku podejście komparatystyczne uznawane było za konieczny składnik teoretycznych i praktycznych wysiłków na gruncie analizy systemów. Celem było określanie podobieństw, podczas gdy różnice uznawano za „odmienności w jedności” (varietas in unitate). W tym duchu F. Bacon w eseju De dignitate augmentis stientiarum z 1623 roku podkreślał konieczność konfrontowania prawa krajowego $\mathrm{z}$ zagranicznym, warunkujące prawidłowe jego funkcjo-

30 N. Machiavelli, Książę, tłum. Cz. Nanke, [w:] Wybór pism, Warszawa 1972; Rozważania nad pierwszym dziesięcioksięgiem historii Rzymu Tytusa Liwiusza, tłum. K. Żaboklicki, [w:] ibidem. U Makiawela podejście komparatystyczne ma wymiar bardziej politologiczny - celem analiz jest sformułowanie praktycznych zaleceń.

31 J. Bodin, Sześć ksiag o Rzeczypospolitej, tłum. Z. Izdebski, Warszawa 1958. Przyjęte założenia metodologiczne przyniosły mu sławę i powszechne uznanie. H. Olszewski, M. Zmierczak, Historia doktryn politycznych i prawnych, Poznań 1994, s. 95. Bodin uchodzi za twórcę metody historycznej w prawoznawstwie oraz tzw. polityki eksperymentalnej. Zrywa $z$ „zaklętym kołem prawa rzymskiego i kanonicznego", łącząc prawoznawstwo z filozofią historii i opierając się na szerokich studiach historycznoporównawczych. Z. Izdebski, Poglądy Jana Bodinusa na państwo i prawo, [w:] J. Bodin, op.cit., s. XXXI. Uznawany jest za ojca realizmu komparatystycznego, polegającego na porównywaniu funkcjonujących rzeczywiście systemów politycznych. H. Izdebski, op.cit., s. 81. To wreszcie autor pierwszej nowożytnej pracy z dziedziny metodologii: Metoda do łatwego poznania historii, [w:] A.R. Nowicki, Filozofia francuskiego Odrodzenia, Warszawa 1973.

32 H. Grotius, Trzy księgi o prawie wojny i pokoju, tłum. R. Bierzanek, Warszawa 1957.

33 T. Hobbes, Lewiatan, czyli materia, forma i władza państwa kościelnego i świeckiego, Kraków 1954.

34 T. More, Utopia, tłum. K. Abgarowicz, Poznań 1947.

35 T. Campanella, Miasto słońca, tłum. L. i R. Brandwajnowie, Wrocław 1955. 
nowanie ${ }^{36}$, a Leibniz w swym Theatrum legale starał się zestawić prawa wszystkich czasów, miejsc i ludzi ${ }^{37}$.

Wzrost zainteresowania problemami ustrojowymi państw wiąże się z epoką Oświecenia, w szczególności powszechnym ożywieniem intelektualnym tego okresu, większym przepływem informacji niż w wiekach wcześniejszych oraz rosnącym zróżnicowaniem rozwiązań ustrojowych poszczególnych państw, które odzwierciedlały poszukiwanie najlepszego sposobu realizacji zasad i idei, jakie legły u ich podstaw ${ }^{38}$. Dla Oświecenia bardzo atrakcyjne okazały się koncepcje należące do szkoły praw natury, co korespondowało z kluczową pozycją problematyki człowieka w myśli prawnej epoki ${ }^{39}$. Porównywanie treści norm prawa natury $\mathrm{z}$ prawem stanowionym uznać można za najtrwalszy bodaj element komparatystyki prawniczej i filozofii prawa w ogóle. Stanowiło to praktyczny oręż w walce o nowy kształt stosunków społecznych: skoro istnieje pewien obiektywny wzorzec (zasady pojawiające się w umyśle ludzkim), to systemy muszą być zbliżone ${ }^{40}$. Co ciekawe, zasady prawnonaturalne były w istocie wynikiem analizy porównawczej ówczesnych systemów prawnych ${ }^{41}$. Widać więc, że rozwój komparatystyki szedł $\mathrm{w}$ parze $\mathrm{z}$ rozwojem świadomości o rosnącym wpływie prawa naturalnego na kształt porządku pozytywnego. W tym kontekście kom-

36 Pierwotna wersja angielska: F. Bacon, Advancement of learning, [w:] Essays Civil and Moral, Advancement of Learning, Novum Organum, London-New York-Melbourne-Sydney 1892.

37 M. Kikkeri, op.cit., s. 15; J. Rajski, Nauczanie prawa porównawczego, Palestra 1962, nr 11, s. 57.

38 B. Banaszak, Porównawcze prawo konstytucyjne współczesnych państw demokratycznych, Kraków 2004, s. 19-20.

39 Wypada tu wspomnieć o J. Locke'u (Dwa traktaty o rzadzie, tłum. Z. Rau, Warszawa 1992) i J.J. Rousseau (Rozprawa o pochodzeniu i podstawach nierówności między ludźmi, [w:] Trzy rozprawy z filozofii społecznej, Kraków 1956; Ekonomia polityczna, [w:] ibidem; Umowa społeczna, Kęty 2002).

40 K. Grzybowski, Historia doktryn politycznych i prawnych, Warszawa 1967, s. 386.

41 R. Tokarczyk, op.cit., s. 52. 
paratystyka może być nazwana „sformalizowanym prawem naturalnym" 42 .

Za prekursora komparatystyki konstytucyjnoprawnej w pełnym tego słowa znaczeniu uznaje się Monteskiusza, a jego $O$ duchu praw to w powszechnej opinii „wprowadzenie do komparatystyki tej gałęzi" ${ }^{43}$ jak i sugestywne świadectwo pożytków płynących z porównywania, które wywarło wielki wpływ na XIX wiek. Wychodząc ze współczesnych mu rozwiązań ustrojowych, autor wskazywał na warunkujące ich kształt okoliczności klimatyczne, historyczne, strukturalne i obyczajowe ${ }^{44}$. W jego doktrynie wyraźnie podkreśla się odmienność kulturalną przy jednoczesnym akcentowaniu podobieństwa na płaszczyźnie ustroju każdego z krajów, dzięki czemu możliwe było powołanie się na argumenty komparatystyczne ${ }^{45}$.

Monteskiusz dokonał podziału istniejących porządków politycznych, redukując kształt każdego $z$ nich od określonego katalogu czynników. Tym samym zróżnicował zasadę legitymizującą sprawowanie władzy w każdym $z$ państw. W jego doktrynie wyraźnie podkreśla się odmienność kulturalną przy jednoczesnym akcentowaniu podobieństwa na płaszczyźnie ustroju każdego z krajów. Dzięki takiemu stanowi rzeczy mógł on, dowodząc słuszności tezy o podziale władz, obok korzystania $z$ materiału indukcyjnego, powołać się na argumenty komparatystyczne ${ }^{46}$.

42 M. Kikkeri, op.cit., s. 29-30.

43 G.L. Seidler, Przedmarksowska myśl polityczna, Kraków 1985, s. 539 .

44 K.L. Monteskiusz, O duchu praw, Kęty 1997, s. 17; W. Wagner, op.cit., s. 47. Dopuścił się on także poważnych błędów, zwłaszcza na płaszczyźnie weryfikacji źródeł czy zbytniego przywiązywania wagi do egzotycznej folklorystyki. R. Tokarczyk, op.cit., s. 53.

45 M. Kikkeri, op.cit., s. 17. Analiza porównawcza ustrojów przeprowadzana jest celem zobrazowania odmiennych rozwiązań praktycznych przyjętych w różnych państwach i dokonywana jest na potrzeby ukazania zasadniczych cech danego teoretycznego modelu ustrojowego. K.L. Monteskiusz, op.cit., s. 27-35.

46 Ibidem, s. 136-160. 
Metodę komparatystyczną zaczęto stosować w szerokim zakresie wraz $z$ wyodrębnieniem się nauki prawa konstytucyjnego ${ }^{47}$. Wiąże się to $z$ wydarzeniami, jakie miały miejsce we Francji, Anglii i Stanach Zjednoczonych na przełomie XVIII i XIX wieku ${ }^{48}$, czyli w istocie $z$ poszukiwaniem nowych form ustrojowych lub też możliwości modyfikacji istniejących porządków. Zabiegi te wynikały $z$ faktu bezdyskusyjnej niemożności sprostania nowym wyzwaniom przez przestarzałe rozwiązania ustrojowe ${ }^{49}$. Od tej pory doktryna konstytucjonalizmu i umowy społecznej roszczą sobie prawo do kształtowania życia społecznego ${ }^{50}$.

Nie sposób zrozumieć wszystkich instytucji ustrojowych bez poznania wcześniejszego ich rozwoju, pobudzonego myślą amerykańskiego oraz europejskiego Oświecenia. Pierwsze konstytucje wyrażały ideały tego okresu: wolność człowieka i prawa naturalne, umowę społeczną, suwerenność ludu, podział władz. Nie sięgano wówczas do przeszłości, gdyż na gruncie konstytucjonalizmu po

47 To zwrot typowy dla kręgu romańskiego i anglosaskiego. Inne synonimiczne kategorie to: prawo polityczne (ujęcie Rousseau) i państwowe (nauka rosyjska i niemiecka). B. Banaszak, Prawo konstytucyjne, s. 3-4.

48 Chodzi tu przede wszystkim o uzyskaniu niepodległości przez dawne kolonie brytyjskie (rewolucja polityczna), które wywarło niemały wpływ na ideologię i kształt kolejnego faktu o kluczowym znaczeniu, czyli Wielką Rewolucję Francuską (rewolucja społeczna). U. Preuss, op.cit., s. 285. Podczas tworzenia konstytucji amerykańskiej J. Madison oraz J. Adams prowadzili badania porównawcze, także w aspekcie historycznym. M. Tushnet, op.cit., s. 1226. Z praktycznego punktu widzenia doniosłe znaczenie dla komparatystyki konstytucyjnej miały działania podjęte $z$ polecenia cesarza Napoleona, obejmujące gromadzenie i analizę rozwiązań prawnych państw obcych. Co ciekawe, prace powołanego w tym celu Komitetu koncentrowały się na prawie publicznym. Zadecydowało o tym podstawowe zamierzenie, jakim było poznanie i przejęcie tych instytucji, które pozwoliłyby cesarzowi na skuteczniejsze sprawowanie władzy. J. Łętowski, Comparative Law Science in So Called Applied Fields of Law, Comparative Law Review 1991, Vol. 2, s. 30 .

49 B. Banaszak, Porównawcze prawo konstytucyjne, s. 28.

50 A. Pieniążek, Suwerenność i państwa narodowe, [w:] Suwerenność i państwa narodowe $w$ integrujacej się Europie - przeżytek czy przyszłość?, Poznań-Warszawa 1995, s. 14. 
prostu jej nie było ${ }^{51}$. Między innymi $z$ tej to przyczyny dochodziło w latach 1789-1815 do tak wielu radykalnych zwrotów ustrojowych. Okres ten nazywa się wręcz „laboratorium form ustrojowych"52.

Kierunek prawnoporównawczy mógł się rozwinąć dopiero na tym poziomie myśli i wiedzy prawniczej, kiedy wywodzenie reguł prawnych $z$ abstrakcji zastąpione zostało indukcyjnym badaniem materiału prawnego. Wielkie zasługi na tym polu przypisać należy szkole prawa natury, szkole historycznej, a nawet etnologii53. Arystoteles za podstawę podejścia komparatystycznego uznał unikalny charakter polis greckich, Machiavelli - fakt sprawowania władzy przez panującego, Bodin - pluralizm religijny, a Monteskiusz - uniwersalną zasadę podziału władzy w zestawieniu $z$ unikalnym charakterem każdego $z$ państw, wynikającym $z$ istoty zamieszkującego go narodu. Wielkie kodyfikacje wieku XVIII zmieniły diametralnie ten stan rzeczy ${ }^{54}$ : od 1787 roku ustroje przestały być oparte wyłącznie na zwyczaju i jedynie nielicznych aktach prawa stanowionego ${ }^{55}$.

51 Istniały dotychczasowe akty konstytucyjne, m.in. Neminem Captivabumus (1433 r.), Statuty nieszawskie (1454 r.), Konstytucja Nihil Novi (1505 r.) w Polsce czy Magna Charta Libertatum (1215 r.), Bill of Rights (1689 r.), Act of Settlement (1701 r.) w Anglii. A. Stambrowski, Egzekutywa według Konstytucji z 1935 r. na tle ustroju typowych państw demokratycznych, Londyn, 1954, s. 3-4. A także Złota bulla Andrzeja II (1222 r.), Przywilej koszycki (1374 r.), Artykuły henrykowskie (1573 r.), Petition of Rights (1628 r.), Agrement of the People (1647 r.). To raczej poręczenia praw stanowych, opis następstwa tronu, ewentualnie próby usprawnienie mechanizmów państwowych. Z kolei karty kolonii amerykańskich uznawały prymat prawa angielskiego, stąd nie stanowiły „prawa najwyższego”. B. Banaszak, Prawo konstytucyjne, s. 57. Słuszna jest więc teza, że „nie istniało wówczas [...] pisane pozytywne prawo konstytucyjne” - K. Grzybowski, op.cit., s. 373.

52 P. Sarnecki, Najstarsze konstytucje, Warszawa 1997, s. 5.

53 K. Sójka-Zielińska, op.cit., s. 837.

54 M. Kikkeri, op.cit., s. 18-20.

55 A. Stambrowski, op.cit., s. 3-4. Dodać należy, że prototypem konstytucji była chaotyczna w swej treści, ale zawierająca wszystkie postanowienia uznawana potem za kanon konstytucyjny Deklaracja Praw Wirginii z 12 VI 1776 r. Inne kamienie milowe tego okresu to: Konstytucja Wirginii z 29 VI 1776 r.; Senatus consultum z 14 thermidora roku X (2 VIII 1802 r.); Senatus consultum organiczne w srawie Konstytucji z 16 thermidora roku X (4 VIII 1802 r.); Senatus consultum z 12 fructidora roku X (30 VIII 
W początkowej fazie badacze koncentrowali się na analizie rozwiązań tylko jednego systemu, celem ich popularyzacji. Alexis de Tocqueville analizuje rozwiązania ustrojowe państw ancient regime, by wydobyć wspólne założenia, stanowiące przyczynę kryzysu porządku feudalnego i jednocześnie składające się na genezę rewolucji francuskiej56. Porównawczą analizę ustrojową znaleźć można i w dziełach B. Constanta, który podaje przykłady rozwiązań ustrojowych wielu państw przy prezentowaniu optymalnej, jego zdaniem, struktury instytucjonalnej państwa ${ }^{57}$. $Z$ tej przyczyny nie można tu jeszcze mówić o komparatystyce sensu stricte, a jedynie pewnej metodzie propagowania założeń konstytucjonalizmu oraz konstytucji jako podstawy państwowego porządku prawnego ${ }^{58}$.

Klęska Napoleona i powrót ancient regime nie zahamował definitywnie badań porównawczych, choć $z$ pewnością spowolnił ich rozwój ${ }^{59}$. Nowym katalizatorem stała się ideologia liberalna oraz rozwój nowoczesnych stosunków kapitalistycznych, które torowały drogę państwu wolnemu od feudalnych więzów. Wówczas to uznawano uchwalenie konstytucji za warunek dokonania przemian politycznych. Szczególnie zamanifestowało się to w trakcie Wiosny Ludów i przekształcaniu monarchii absolutnych w konstytucyjne, kiedy doszły do głosu tłumione okresem restauracji aspiracje narodów ${ }^{60}$. Kres XVIII i 1. połowa XIX wieku to swoiste „przecieranie szlaków", przynoszące mniej lub bardziej trwałe rezultaty ${ }^{61}$.

1802 r.); Senatus consultum organiczne z 28 frimaire'a roku XII (20 XII 1803 r.) oraz Karta Konstytucyjna Francji z 4 VI 1814 r. P. Sarnecki, op.cit., s. 6.

56 A. de Tocqueville, Dawne rzady a rewolucja, Warszawa 1907, s. 18-22 i 48-51. Podobnie jak Monteskiusz, podkreślał on, że rozwiązania właściwe dla pewnego narodu mogą okazać się szkodliwe dla innych społeczeństw.

57 Ma to wymiar tak historyczny, jak i współczesny. B. Constant, O monarchii konstytucyjnej $i$ rękojmiach publicznych, Warszawa 1831, s. 61-62, 65.

58 B. Banaszak, Porównawcze prawo konstytucyjne, s. 28.

59 Co ciekawe, $\mathrm{w}$ dobie zaborów polskich prawników zmuszono niejako do analizy porównawczej, co trwało do 1947 r. R. Tokarczyk, op.cit., s. 9.

60 B. Banaszak, Porównawcze prawo konstytucyjne, s. 29-30.

61 P. Sarnecki, op.cit., s. 5. 
Zainteresowanie obcymi rozwiązaniami ustrojowymi, tak na płaszczyźnie teoretycznej, jak i praktycznej, to zjawisko występujące na szerszą skalę od 2. połowy XIX wieku. Coraz silniej zaznacza się oddziaływanie wpływów ustrojowych i prawnych państw przodujących politycznie i gospodarczo ${ }^{62}$. Czerpano $z$ obcych rozwiązań, podejmując wiele eksperymentów ustrojowych. Wiek XIX uznać można za zwycięstwo idei konstytucjonalizmu i koncepcji prawnej legitymacji władzy, co wiąże się z rosnącym wpływem angielskich założeń ustrojowych na rozwój konstytucjonalizmu kontynentalnego ${ }^{63}$.

Jednocześnie komparatystyka przyjęła narodowe podejście, zakładając a priori istnienie odmienności między systemami prawa, postrzeganymi bardziej niż we wcześniejszych wiekach w powiązaniu $z$ aspektem społecznym czy szerzej: kulturowym ${ }^{64}$. Szczególną w tym rolę przypisać należy niemieckiej szkole historycznej, dezawuującej znaczenie i możliwości praktycznej komparatystyki. Jednocześnie podkreślała ona specyficzny charakter każdego $z$ systemów prawa, warunkowany tzw. duchem narodu (Volksgeist) ${ }^{65}$. Zdaniem von Savigny'ego istnieje „organiczny związek prawa $z$ bytem i charakterem narodu”66. „Zjawiska te [tj. prawo, mowa, obyczaje i ustrój] nie mają nawet oddzielnego bytu, są tylko pojedynczymi

62 Chodzi głównie o Francję oraz Wielką Brytanię. Ch. Saunders, op.cit., s. 37 .

63 J. Bardach, Metoda porównawcza, s. 14.

64 W. Wagner, op.cit., s. 47. Popularność zaczęły wówczas zdobywać organiczne teorie państwa i prawa, co wiązało się $z$ przechodzeniem od oświeceniowego racjonalizmu do romantyzmu. To także wkroczenie w erę nacjonalizmów, która traci swą wyrazistość dopiero po II wojnie światowej. M. Kikkeri, op.cit., s. 16, 20-21.

65 Siedliskiem prawajest wspólna świadomość narodu. K.F. von Savigny, O powołaniu naszych czasów do ustawodawstwa i nauki prawa, tłum. K. Opałek, Warszawa 1964, s. 56.

66 Ibidem. „Wszelkie prawo powstaje drogą [...] zwyczajową, to znaczy jest wytwarzane najpierw przez obyczaj i przekonania narodu, a potem przez jurysprudencję" - ibidem, s. 58. 
funkcjami tego samego narodu", a znaczenie historii w określaniu ich treści jest kluczowe ${ }^{67}$.

Na przełomie XIX i XX wieku przesłankę dla rozwoju komparatystyki konstytucyjnej stanowiła możliwość dokonywania wymiany kulturalnej w warunkach, jeśli nie życzliwej współpracy, to przynajmniej braku otwartej wrogości ${ }^{68}$. Wcześniejsze trudności w komunikacji między narodami wynikały m.in. $z$ braku zaufania i powszechnej nieznajomości rozwiązań ustrojowych innych państw, które - jeśli ich kształt był znany - uznawano za mniej rozwinięte lub po prostu błędne ${ }^{69}$. Słynny kongres paryski z 1900 roku pobudził zainteresowanie systematycznymi studiami porównawczymi, wywołując jednocześnie wątpliwości, czy rozwój środków przekazu i kanałów informacyjnych nie doprowadzi do znacznego ujednolicenia systemów prawa, co przesądziłoby o obniżeniu wartości samej komparatystyki ${ }^{70}$.

67 Ibidem, s. 54. Teraźniejszość to organiczny wytwór przeszłości, a narodowa historia to skarbnica najwyższych wartości i nauczycielka życia. H. Olszewski, Nauka historii $w$ upadku, Warszawa-Poznań 1982, s. 33. Koncentrując się na analizie jednostkowych faktów historycznych, potępiono próby unifikacji dokonywane w duchu koncepcji prawa natury. Podobny sceptycyzm cechował doktrynę pozytywizmu, koncentrującą się na analizie norm, z pominięciem szerszego kontekstu. Zdecydowany atak na powyższe założenia przeprowadzili Feuerbach i Ihring, co stanowiło wyraz nowych potrzeb. K. Sójka-Zielińska, W sprawie oceny romanistycznego i germanistycznego kierunku szkoły historycznej $w$ niemieckiej nauce prawa I pot. XIX w., Czasopismo Prawno-Historyczne 1959, nr XI, z. 2, s. 129-143; K. Opałek, J. Wróblewski, Niemiecka szkoła historyczna $w$ teorii prawa, Przegląd Nauk Historycznych i Społecznych 1954, s. 237 i n.; K. Grzybowski, O miejscu niemieckiej szkoły historycznej $w$ rozwoju nauki prawa, Czasopismo Prawno-Historyczne 1956, nr VIII, z. 2, s. 338 i n.

68 Zainteresowanie obcymi porządkami jest silniejsze w dobie przyjaznych relacji międzynarodowych i prosperity. Widać więc wyraźną zależność między komparatystyką a treścią stosunków międzynarodowych. R. Tokarczyk, op.cit., s. 10.

69 W. Wagner, op.cit., s. 45-46.

70 R.R. Ludwikowski, Prawo konstytucyjne porównawcze, s. 21-22. 
W okresie dwudziestolecia zachęcano organizujące swą państwowość narody do przyjmowania pewnych rozwiązań systemowych ${ }^{71}$ i czerpania ze sprawdzonych wzorców ${ }^{72}$. Twórcy konstytucji wyzwolonych w XX wieku państw zwracali się po pomoc do doświadczonych specjalistów konstytucjonalizmu z Europy Zachodniej i Stanów Zjednoczonych. Zasadniczymi kwestiami do rozstrzygnięcia były problemy wypracowania precyzyjnego języka, który miał być użyty w nowych ustawach zasadniczych ${ }^{73}$.

Czas totalitaryzmów przerwał rozwój wielu ustrojów demokratycznych, a państwa zmuszone były budować porządki polityczne w duchu narzuconej ideologii ${ }^{74}$. Prawodawstwo stało się tylko jednym $z$ narzędzi prowadzenia ekspansjonistycznej polityki ${ }^{75}$. W III Rzeszy formalnie obowiązująca konstytucja Republiki Weimarskiej pozbawiona została praktycznego znaczenia ${ }^{76}$. Krytyka pozytywistycznych koncepcji państwa i prawa uczyniła w 1933 roku ustawodawstwo domeną rządu ${ }^{77}$. Wkrótce zanikła faktyczna różnica między ustawą konstytucyjna a zwykłą, potem - między ustawą a rozporządzeniem ${ }^{78}$. Utożsamianie prawa $z$ wolą Führera czyniło zeń zjawisko o charakterze ekskluzywnym, uniemożliwiając jakiekolwiek analizy porównawcze. „Mechanizm prawodawczy sprzęgał się zatem w działaniu $z$ mechanizmem rządzenia sensu stricte"79.

Początkowo totalitaryzm radziecki dezawuował wartość prawa „Komunizm nie oznacza zwycięstwa socjalistycznego prawa, lecz zwycięstwo socjalizmu nad wszelkim prawem, ponieważ wraz ze zniesieniem klas mających antagonistyczne interesy prawo zniknie

71 Np. polska konstytucja z 17 III 1921 r. wzorowana była na konstytucji francuskiej z $1875 \mathrm{r}$.

72 Np. Statut Westminsterski z 1931 r., [w:] B. Winiarski, Wybór źródeł do nauki prawa międzynarodowego, Warszawa 1938, s. 527-531.

73 M. Tushnet, op.cit., s. 1228.

74 R.R. Ludwikowski, Prawo konstytucyjne porównawcze, s. 25-26.

75 F. Ryszka, Państwo stanu wyjątkowego, Wrocław-Warszawa-Kraków-Gdańsk-Łódź 1985, s. 267-270.

76 Ibidem, s. 265

77 Ibidem, s. 273.

78 Ibidem, s. 283.

79 Ibidem, s. 291. 
całkowicie"80. Oznaczało to stopniowy zanik prawa jako takiego na rzecz bezpośredniego, technologicznie zdeterminowanego zarządzania w postaci programów produkcji i dystrybucji: „całe prawo przekształca się w zarządzanie, wszelkie stałe przepisy - w samodzielne decyzje i zalecenia podporządkowane względom praktycznym" ${ }^{81}$. Stanowiło to zaprzeczenie zasad państwa prawa i zwolnienie rządzących $z$ wszelkiej odpowiedzialności ${ }^{82}$.

$\mathrm{Z}$ czasem prawo demokracji ludowych nabrało typowego dla porządków autokratycznych waloru wyjątkowości. Wiąże się to z faktem, że działalność rządzących przybierała często charakter pozaprawny ${ }^{83}$, a „zasada nadrzędności Konstytucji nie była w ogóle gwarantowana” ${ }^{44}$. Aparat władzy „decydował o treści aktów prawnych, o ich interpretacji i stosowaniu"85: law in action stanowiło dzieło funkcjonariuszy ${ }^{86}$. Prawo było stronnicze i celowo niejasne, a przepisy z premedytacją mnożono, doprowadzając tym samym do licznych sprzeczności. „Stosowano [je] jako zasłonę dla w istocie bezprawnych i poza tym nieetycznych działań władzy" ${ }^{87}$. Inną kwestią była „swoista poetyka prawna socrealizmu”, w której wyrażała się funkcja ideologiczna prawa ${ }^{88}$. Zasadniczym celem powyższych działań było utrzymanie się u władzy komunistycznych elit ${ }^{89}$.

Inną przesłanką negatywną dla rozwoju komparatystyki konstytucyjnej była funkcjonująca zasada pośredniego stosowania ówcze-

80 Cytat za: F.A. von Hayek, Konstytucja wolności, Warszawa 2006, s. 238 .

81 W. Friedmann, Law and Social chnage in Contemporary Britain, Londyn 1951, s. 154.

82 F.A. von Hayek, op.cit., s. 238.

83 J. Karpiński, Ustrój komunistyczny w Polsce, Warszawa 2005, s. $73-75$.

84 P. Tuleja, Stosowanie Konstytucji RP w świetle zasady jej nadrzędności, Kraków 2003, s. 379.

85 J. Karpiński, op.cit., s. 100.

86 Ibidem, s. 124-125.

87 Ibidem, s. 121.

88 Ibidem, s. 123-124.

89 Ibidem, s. 102-103. 
snej konstytucji ${ }^{90}$. Powszechnie obowiązujący dogmat o pełnej realizacji interesów ludu pracującego na drodze stanowienia i stosowania norm prawnych czynił z kontroli konstytucyjności aktów prawnych zagadnienie marginalne. „Punktem wyjścia musi być bezsporne stwierdzenie, że działalność ustawodawcza i kontrolna Sejmu nie podlegają ocenie sądów, jako organów wymiaru sprawiedliwości"91. Uzasadnieniem była troska o suwerenność państwa i ludu pracującego oraz jednolitość władzy państwowej92. Pozaparlamentarna kontrola sądowa prawa utożsamiana była $z$ rządami kapitału ${ }^{93}$. Ponadto podważałaby zasadę prymatu Sejmu jako naczelnego organu władzy ${ }^{94}$. Stanowiło to konsekwencję wpływu wzorców radzieckich, w szczególności koncepcji „dyktatury proletariatu"95.

Z czasem oficjalne poglądy uległy zmianie ${ }^{96}$. „Należy przypuszczać, iż działalność TK służyć będzie nie tylko uwiarygodnieniu zasady praworządności socjalistycznej, ale także zwierzchnictwa ludu pracującego miast i wsi”97. „Trybunał udowodni społeczną przydatność w umacnianiu porządku konstytucyjnego socjalistycz-

90 Prawo konstytucyjne, red. Z. Witkowski, s. 34-35. Nadawało to jej normom charakter czysto programowy. Prawo konstytucyjne, red. P. Sarnecki, s. 12-13; P. Tuleja, Podstawowe problemy zwiazane z interpretacja Konstytucji RP w orzecznictwie TK, [w:] Księga XX-lecia, s. 209.

91 A. Szpunar, Odpowiedzialność Skarbu Państwa za funkcjonariuszy, Warszawa 1985, s. 101.

92 L. Bosek, Bezprawie legislacyjne, Warszawa 2007, s. 51-52.

93 S. Rozmaryn, Kontrola konstytucyjności ustaw, Państwo i Prawo 1948, nr 11, s. 49-50.

94 A.M. Ludwikowska, Sacdownictwo konstytucyjne $w$ europie Środkowo-Wschodniej, Toruń 2002, s. 12-13.

95 J. Surowiec, Ewolucja poglądów na instytucję sądowej kontroli konstytucyjności ustaw w PRL, [w:] Trybunał Konstytucyjny, Wrocław 1987, s. $12-14$.

96 Dwunasta nowelizacja Konstytucji PRL (26 III 1982 r.) wprowadziła TK, pozbawiając Radę Państwa kompetencji przyznanej jej w wyniku dziesiątej nowelizacji (10 II 1976 r.) czuwania nad zgodnością prawa z Konstytucją. M. Kallas, A. Lityński, Historia ustroju i prawa Polski Ludowej, Warszawa 2000, s. 118-124 i 157-158.

97 J. Surowiec, op.cit., s. 30. 
nego państwa" ${ }^{98}$. Podkreślano rozdział i podrzędność ç9 $^{99}$ nowego organu względem Sejmu ${ }^{100}$. Niezależnie od oficjalnie głoszonych poglądów ${ }^{101}$, przez cały okres swego istnienia był to porządek chroniący system, a nie jednostkę, sprzeczny z zasadami państwa prawa $^{102}$, obejmującymi także zasady prawidłowej legislacji, determinowane $\mathrm{m}$.in. kształtem systemu instytucjonalnego ${ }^{103} \mathrm{i}$ poziomem kultury politycznej ${ }^{104}$.

W związku z powyższym w dobie tzw. realnego socjalizmu komparatystyka konstytucyjna sprowadzała się do zestawiania rozwiązań ustrojowych państw demokracji ludowej z modelami tzw. demokracji burżuazyjnej celem uzasadnienia $z$ góry przyjętego wniosku o wyższości tych pierwszych, czerpiących ze wzorców radzieckich ${ }^{105}$. Instytucje powyższych porządków były sobie przeciwstawne, a ponadto tylko w ustroju socjalistycznym ich struktura gwarantowała realizację najszczytniejszych postulatów, co podkreślano przy każdej nadarzającej się okazji ${ }^{106}$. „Teza o wyższości prawa typu socjalistycznego nad burżuazyjnym zostaje znacznie wzbogacona wnioskami płynącymi z badań porównawczych"107.

98 Z. Czeszejko-Sochacki, Trybunał Konstytucyjny PRL, Warszawa 1986, s. 6.

99 J. Repel, Trybunał Konstytucyjny, a zasada nadrzędności Sejmu, [w:] Trybunat Konstytucyjny, s. 139.

100 J. Trzciński, Charakter podstawowej działalności TK, [w:] ibidem, S. 85 .

101 J. Mazur, Planowanie tworzenia prawa $w$ państwie socjalistycznym, Warszawa 1986, s. 143.

102 L. Bosek, op.cit., s. 53-54.

103 E. Popławska, Lepsze prawo-wyzwanie dla Senatu, [w:] Tryb ustawodawczy a jakość prawa, Warszawa 2005, s. 114-115.

104 J. Wawrzyniak, Inicjatywa ustawodawcza - teoria, prawo, praktyka, [w:] ibidem, s. 31-32.

105 Np. J. Ciemniewski, Sprawozdanie z VII sesji katedr prawa państwowego $w$ Warszawie, Państwo i Prawo 1965, nr 8-9, s. 387.

106 K. Biskupski, W związku z podręcznikiem prawa państwowego, Państwo i Prawo 1958, nr 11, s. 789; idem, Sesja naukowa katedr prawa państwowego w Toruniu, Państwo i Prawo 1960, nr 11, s. 875-878. S. Gebethner, Cypr: państwo suwerenne czy kondominium?, Prawo i Życie 1959, nr 6, s. 6.

107 J. Rajski, op.cit., s. 57. 
Zdarzały się także prace obierające za przedmiot zainteresowania tylko systemy polityczne (i instytucje ustrojowe) państw bloku wschodniego $^{108}$. Choć wychodziły one $z$ metodologicznie poprawnych założeń, ukazując nie tylko samą regulacje prawną, lecz także praktykę jej funkcjonowania i genezę jej współczesnego kształtu, to rzetelność i obiektywizm doboru materiału empirycznego pozostawiały wiele do życzenia. Daje to asumpt to określenia inspiracji tego typu analiz jako skrajnie politycznych, by nie rzec instrumentalnych ${ }^{109}$. „Konstytucje republik ludowych stanowią nie tylko utrwalenie wywalczonych pozycji politycznych i ekonomicznych, ale zawierają także programowe przepisy o zwycięstwie socjalizmu" ${ }^{110}$. Wywodzone wnioski stanowiły co najwyżej próby pewnego generalizowania i określania („słusznych”) kierunków rozwojowych. Brak było jakiegokolwiek wartościowania badanych modeli, co tłumaczyć należy względami politycznymi. Autorzy opracowań starali się wykazać istnienie wspólnych zasad ustrojowych wszystkich państw demokracji ludowej, stanowiących wspólny mianownik ich porządków politycznych ${ }^{111}$. Analizowano m.in. odmiany dyktatury proletariatu, specyfikę walki klasowej ${ }^{12}$.

108 Np.: J. Ciemniewski, op.cit., s. 381-388; Gasudarstwiennoje prawo stran narodnoj demokratki, red. A. Machnienka, Moskwa 1959; Gasudarstwiennoje prawo zarubieżnych socjalisticzeskich stran, red. W. Kotok, Moskwa 1957.

109 K. Gościniak, Z. Jarosz, Recenzja pracy Gasudarstwiennoje prawo zarubieżnych socjalisticzeskich stran, Państwo i Prawo 1958, nr 11, s. 840. Ocena sfery formalnej w zestawieniu z praktyką dopuszczalna była w socjalizmie na zasadzie wyjątku w postaci tzw. wartościowania wtórnego. J. Wróblewski, op.cit., s. 22-32.

110 Gasudarstwiennoje prawo zarubieżnych socjalisticzeskich stran, za: K. Gościniak, Z. Jarosz, op.cit., s. 843.

111 R. Klimowiecki, Problem dekretowy $w$ Sejmie, Prawo i Życie 1956, nr 10, s. 2.

112 W. Skrzydło, Recenzja pracy "Gasudarstwiennoje prawo stran narodnoj demokratki", red. A. Machnienka, Moskwa 1959, Państwo i Prawo 1960, nr 11, s. 853. Na uwagę zasługuje praca B. Dobkowskiego, Zasada suwerenności ludu w konstytucjach europejskich państw socjalistycznych, Warszawa 1988, gdzie znaleźć można nieśmiałe krytyczne uwagi o mankamentach ówczesnego ustroju, m.in. s. 14, 111-112, 241, 247, 284-285. 
Badania porównawcze zintensyfikowały się dzięki nowelizacjom ustaw zasadniczych państw Europy Zachodniej oraz procesowi dekolonizacji w latach 60. XX wieku ${ }^{113}$. Przełomowym wydarzeniem było powołanie niemieckiego Federalnego Trybunału Konstytucyjnego, który stał się drugim, obok Sądu Najwyższego Stanów Zjednoczonych, sądem konstytucyjnym dokonującym kreatywnej i dynamicznej wykładni przepisów konstytucji. Duży wpływ miało także uchwalenie konstytucji Kanady ${ }^{114}$. Nie bez znaczenia pozostaje proces demokratyzacji państw Ameryki Południowej, dostarczający interesujących materiałów badawczych ${ }^{115}$.

Wzrost zainteresowania problematyką prawnoporównawczą w Stanach Zjednoczonych w 2. połowie XX wieku stanowił następstwo wielkiego politycznego, militarnego i gospodarczego zaangażowania Ameryki w wydarzenia światowe ${ }^{116}$. Niewątpliwie przyczyniła się także do tego duża liczba imigrantów z Europy lat 30., będących najczęściej uchodźcami politycznymi, którzy rozpoczęli swą działalność naukową na wielu amerykańskich uczelniach wyższych.

113 J. Jakubowski, Z problematyki metodologicznej badań prawno-porównawczych, Państwo i Prawo 1963, nr 7, s. 8; J. Kayode Fayemi, Entrenching Independent Institutions in the Constitution-Making Process - Issues and Options for Consideration, [w:] Constitutionalism in Transition, s. 206-207; R. Henwood, op.cit., s. 108-110; Z. Biskupski, Ustroje konstytucyjne Afryki, Zeszyty Naukowe UMK, Prawo IV, nr 10, s. 13-26.

114 Podobnie jak przyjęcie w tym państwie Karty Praw $i$ Wolności (Charter of Rights and Freedoms) w latach 80., a to ze względu na przeprowadzenie analizy roli i funkcji konstytucji w relacji do kategorii tożsamości narodowej. M. Tushnet, op.cit., s. 1227-1228.

115 A.M. Aronovitz, Some Reflections on the Possible Role Played by Constitutional Culture in the Preservation of Democratic Values in Latin America, [w:] Constiutional Cultures, s. 123-134; L. Garlicki, Trybunały konstytucyjne w Ameryce Łacińskiej, [w:] Państwo. Ustrój. Konstytucja, Lublin 1994.

116 W szczególności w zakresie pomocy udzielonej państwom Europy zmagającym się z III Rzeszą oraz organizowania nowego porządku powojennego w atmosferze pierwszych lat zimnej wojny. W.J. Wagner, Comparative Law: Its Methodology and Development in the United States, Comparative Law Review 1991, Vol. 2, s. 5-7. 
Po II wojnie losy komparatystyki znaczą okresy napięć i odprężeń w stosunkach międzynarodowych. Tak zwana prawna komparatystyka negatywna zabezpieczać je miała przed wykorzystywaniem do celów politycznych. Choć badano w ograniczonym zakresie obce systemy (tzw. koncepcja minimalistyczna komparatystyki prawnej), to nie doceniano kontekstu filozoficznego, ideologicznego i politycznego ${ }^{117}$. Niemniej od 1945 roku ponad połowa członków ONZ przeprowadziła u siebie fundamentalną reformę prawa konstytucyjnego.

Upadek bloku wschodniego, zapoczątkowany w 1989 roku, i kres zimnej wojny oznaczał utęsknione pokojowe współistnienie i współpracę, ale i konieczność zaprowadzenia nowego ładu na obszarze Europy Środkowo-Wschodniej ${ }^{118}$. Wiele państw stanęło w obliczu konieczności przeprowadzenia reform ustrojowych, jakich domagała się zdecydowana większość społeczeństwa. Powrót do rozwiązań sprzed okresu niewoli nie był niemożliwy, a to za sprawą postępującego rozwoju cywilizacyjnego. W tym kontekście badania porównawcze dostarczyły materiału użytecznego przy tworzeniu własnych instytucji politycznych ${ }^{119}$. Proces uchwalania nowych ustaw zasadniczych stał się szczególnie intensywny, gdyż każde z państw miało ambicję opracowania własnej nowej konstytucji lub gruntownej nowelizacji aktów istniejących ${ }^{120}$. Można powiedzieć, że rejon uprzedniej dominacji ZSRR stał się „laboratorium konstytucyjnym”, „mekką” dla specjalistów od nowo tworzącej się dyscypliny, tzw. inżynierii konstytucyjnej (constitutional engineering), uczącej pisa-

117 R. Tokarczyk, op.cit., s. 58-59.

118 E. Kośmicki, op.cit., s. 39.

119 Na tym tle szczególnie widać aktywność ośrodków prawa konstytucyjnego porównawczego. B. Banaszak, Porównawcze prawo konstytucyjne, s. 33-34. Na tym tle szczególnie widać aktywność ośrodków prawa konstytucyjnego porównawczego.

120 Nowe konstytucje pojawiły się w Albanii, Armenii, Azerbejdżanie, Białorusi, Bułgarii, Czechach, Estonii, Gruzji, Kazachstanie, Kirgizji, Litwie, Polsce, Słowacji i Ukrainie. Systemy polityczne państw Europy Środkowej i Wschodniej. Ustrój, organy władzy, partie polityczne, red. M. Barański, Katowice 2005. 
nia nowych konstytucji ${ }^{121}$. Wraz z powszechną aprobatą wzrostu funkcji państwa porównywano rozwiązania powstałe w różnych obszarach ideologicznych, co stanowiło także punkt wyjścia dla nowych regulacji. Wielką rolę w tym zakresie odegrały sądy konstytucyjne, powstające licznie przez uchwaleniem nowych ustaw zasadniczych. „Kontrola konstytucyjności prawa stała się największą innowacją postkomunistycznego konstytucjonalizmu wschodnioeuropejskiego” 122 . „Orzecznictwo sądów konstytucyjnych nie sprowadza się do ochrony konstytucji [...], ale także do przeszczepiania na grunt prawa wewnętrznego zasad prawnych o charakterze uniwersalnym" ${ }^{123}$. Orzeczenia wykorzystujące dorobek polskiej nauki prawa konstytucyjnego i standardy międzynarodowe antycypowały przyszłe rozwiązania ustrojowo-prawne ${ }^{124}$.

Reasumując, burzliwy rozwój komparatystyki konstytucyjnej pod koniec XX wieku spowodowany był kilkoma czynnikami. Przede wszystkim było to pojawienie się palącej potrzeby stworzenia demokratycznych instytucji oraz wprowadzenia konstytucjonalizmu. $Z$ drugiej strony silnym katalizatorem okazał się entuzjazm odzyskujących wolność narodów, pragnących demokracji w miejsce systemów autokratycznych. Po trzecie w dobie rosnących współzależności w interesie każdego $\mathrm{z}$ państw leży funkcjonowanie „znośnego" porządku ustrojowego we wszystkich krajach regionu ${ }^{125}$.

121 M. Gulczyński, Panorama systemów politycznych świata, Wydawnictwo Sejmowe, Warszawa 2004, s. 69-86. Czasem stosuje się określenie „ogrodnictwo (gardening) konstytucyjne”, by podkreślić selektywny dobór zapożyczanych instytucji („sadzonek”) oraz brak sztywnych granic działań, czego nie spotyka się we wspomnianej inżynierii tudzież chirurgii (surgery) konstytucyjnej. R.R. Ludwikowski, Constitutional Culture, s. 60-63. Powstał program Central and East European Law Initiative, polegający na wsparciu przez prawników amerykańskich rozwoju i przekształcaniu prawa w państwach byłego bloku wschodniego. A.M. Ludwikowska, op.cit., s. 14.

122 Ibidem, s. 271.

123 Ibidem, s. 279.

124 M. Mazurkiewicz, Orzecznictwo Trybunału Konstytucyjnego jako inspiracja w pracach nad Konstytucją z dnia 2 kwietnia 1997 r., [w:] Księga XX-lecia, s. 200-201.

125 M. Tushnet, op.cit., s. 1227-1228. 


\section{Próba oceny}

Za warunek niezbędny dla rozwoju komparatystki konstytucyjnej uznaje się funkcjonowanie w świadomości ludzi przeświadczenia o możliwości dokonania kreacji i wyboru rozwiązań ustrojowych, a nie tylko konieczności przyjmowania gotowych modeli ${ }^{126}$. Porównywanie stało się faktem, gdy społeczności osiągnęły pewien poziom samoświadomości własnych rozwiązań ustrojowych i jednocześnie otworzyły się na inne grupy ludzkie ${ }^{127}$. $Z$ drugiej strony istnieć musi pewna liczba pisanych konstytucji (ewentualnie aktów prawa o tożsamej funkcji, gdyż nowoczesne znaczenie pojęcia „konstytucja” przyniósł dopiero przełom XVIII i XIX wieku) ${ }^{128}$, mogących stanowić przedmiot badań i stanowiących coś więcej niż tylko ramy dla funkcjonowania państwa (władzy). Znajduje to przełożenia na specyficzny charakter relacji między treścią ich postanowień a aktualnie działającymi instytucjami porządku społecznego ${ }^{129}$.

$Z$ jednoznaczną samodzielnością gałęzi prawa konstytucyjnego koresponduje wyodrębnienie się komparatystyki przedmiotu $\mathrm{w}$ nową, samodzielną dyscyplinę naukową ${ }^{130}$. Nie jest to sprawa oczywista, gdyż wielu powszechnie uznanych komparatystów, wśród nich Gutteridge, a za nim M. Ancel i R. David, przyznaje sferze badań prawnoporównawczych jedynie status metody (ewentualnie grupy metod), a nie samodzielnej dyscypliny naukowej ${ }^{131}$. Nie zmienia to faktu, że komparatystyka nawet jako samodzielna dziedzina ma wymiar interdyscyplinarny ${ }^{132}$.

126 Bliskie jest to założeniom tzw. społeczeństwa otwartego K.R. Poppera, którym dał on wyraz w swej książce Społeczeństwo otwarte i jego wrogowie, t. 1, Warszawa 2006, s. 377-378.

127 R. Tokarczyk, op.cit., s. 47.

128 B. Banaszak, Porównawcze prawo konstytucyjne, s. 52-53.

129 M. Tushnet, op.cit., s. 1226.

130 B. Banaszak, Porównawcze prawo konstytucyjne, s. 19-20.

131 Zweigert i Kötz mówią o „podstawie tworzenia nowego porządku prawnego", która to opinia nawiązuje do XIX-wiecznego ruchu kodyfikacyjnego w Niemczech, który „Zsyntetyzował” niejako dotychczasowe prawo poszczególnych Landów w jeden nowy system. R. Tokarczyk, op.cit., s. 29.

132 J. Wróblewski, op.cit., s. 15. 
Przedmiot badań ewoluował. Początkowo był to raczej zwyczaj, ewentualnie prawo zwyczajowe, gdyż przez wieki istniała jedynie niewielka liczba aktów zawierających normy prawa stanowionego. $Z$ tej przyczyny wczesne analizy bliższe były dziedzinie nauk politycznych ${ }^{133}$. Dziś jest nim prawo konstytucyjne, gałąź prawa publicznego systemu krajowego ${ }^{134}$. Współcześnie chodzi przede wszystkim o prawo w ujęciu pozytywnym (mikrojednostki prawa: normy, instytucje, oraz makrojednostka prawa: gałąź) ${ }^{135}$. Jednak w toku badań nie wolno zapominać o pozaustawowych źródłach prawa, m.in. zwyczaju konstytucyjnym, uzupełniającym i rozwijającym obowiązujące regulacje pozytywne ${ }^{136}$. Zachodzące współcześnie zjawiska globalizacji, budzące tak ambiwalentne emocje, doprowadzić mogą do pewnego zbliżenia kultur narodowych, a w związku z tym - do zbliżenia przedmiotów zainteresowań badaczy prawa konstytucyjnego ${ }^{137}$.

Antyczna „komparatystyka konstytucyjna” pełniła diametralnie inne funkcje niż dzisiejsza: stanowiła narzędzie poznania i opisu rzeczywistości, przyczyniając się tym samym do rozwoju prawa i myśli prawnej: było to sui generis komentowanie różnorodności ${ }^{138}$, w którym chodziło jednak także o podkreślanie różnic między barbarzyńcami a narodami cywilizowanymi (element wartościowania) ${ }^{139}$. Stosownie do upływu czasu, spektrum celów i funkcji porównywania rozwiązań politycznych systemów ulegało stałemu poszerzaniu i ewolucji. Metody porównawcze służyły jako środek

133 M. Kikkeri, op.cit., s. 13, 26-27. Od 1787 roku ustroje przestały być oparte wyłącznie na zwyczaju i jedynie nielicznych aktach prawa stanowionego. Ibidem, s. 18-20.

134 Uzyskała ona samodzielność na przełomie XVIII i XIX wieku. U. Preuss, op.cit., s. 285.

135 Mikrokomparatystyka w ujęciu praktycznym dominowała do lat 60. M. Tushnet, op.cit., s. 1227-1228. W. Sokół, Geneza i ewolucja systemów wyborczych w państwach Europy Środkowej $i$ Wschodniej, Lublin 2007, s. 10.

136 M. Kikkeri, op.cit., s. 38.

137 J. Łętowski, op.cit., s. 22.

138 R. Tokarczyk, op.cit., s. 49.

139 W. Kornatowski, Rozwój pojęć na państwo w starożytnej Grecji, Warszawa 1950, s. 294. 
argumentacji w renesansowych i barokowych uczonych traktatach. Od XVIII wieku to przede wszystkim sposób propagowania preferowanych rozwiązań ustrojowych, a od końca stulecia - praktyczne narzędzie w rękach legislatorów. Widać, jak bogaty wachlarz celów i funkcji komparatystyki prawa konstytucyjnego można dziś poznawać i analizować.

„Potwierdźmy zatem, że okres izolacjonizmu prawniczego, który $z$ nauki prawa uczynił studia o partykularystycznym charakterze nad stosunkami ograniczonymi w czasie i przestrzeni dobiegł już swego końca" ${ }^{140}$. Rozprawom doktorskim i habilitacyjnym niezawierającym elementów komparatystycznych zarzuca się niekompletność ${ }^{141}$. Analiza konstytucyjnoporównawcza pozwala określić pewne generalne cechy ustroju ${ }^{142}$. Poza działalnością naukową ${ }^{143}$, nie pozostaje omawiana dziedzina bez znaczenie dla dydaktyki ${ }^{144}$.

140 J. Rajski, op.cit., s. 56.

141 J. Łętowski, op.cit., s. 21-22.

142 M. Tushnet, op.cit., s. 1240.

143 Zagadnienia $z$ zakresu prawa konstytucyjnego stanowiły przedmiot zainteresowania naukowców skupionych wokół międzynarodowego Wydziału Prawa Międzynarodowego. J. Rajski, Letnia Sesja Międzynarodowego Wydziału Prawa Porównawczego, Prawo i Życie 1961, nr 19, s. 6; idem, Wiosenna Sesja Międzynarodowego Wydziału Prawa Porównawczego, Prawo i Życie 1962, nr 12, s. 7. Organizowane są konferencje naukowe, m.in. Kultury Konstytucyjne (Centrum Konstytucjonalizmu i Kultury Prawnej Instytutu Spraw Publicznych, Warszawa 1999) oraz Międzynarodowa Konferencja Konstytucjonalizmu Porównawczego. Konstytucjonalizm w dobie przemian. Afryka i Europa Wschodnia (Helsińska Fundacja Praw Człowieka i Fundacja Forda, Warszawa 2001).

144 Studia dotyczące prawa socjalistycznego zastąpione zostały wykładami z problemów transformacji ustrojowych państw Europy Środkowo-Wschodniej. Pojawiły się koncepcje mówiące o konieczności badania porządków prawnych poszczególnych, najczęściej sąsiadujących ze sobą regionów świata. Jednocześnie rozwijać zaczęła się komparatystyka poszczególnych dziedzin prawa. B. Banaszak, Porównawcze prawo konstytucyjne, s. 33-34. Analizę porównawczą ewolucji instytucji, a nawet całych ustrojów można przedstawić w ujęciu historycznym, co jest szczególnie przydatne w procesie dydaktycznym, dzięki określeniu pewnych trendów rozwojowych możliwa jest generalizacja, a co za tym idzie - unikanie powtórzeń. Ibidem, s. 847. Istnieją dwa stanowiska co do sposobu prowadzenie zajęć z przedmiotu. W.J. Wagner, Comparative law, s. 8. 
Wzrasta przydatność analiz prawnoporównawczych dla prac legislacyjnych ${ }^{145}$. Słownik terminów konstytucyjnych „zaczął być pisany wspólnym językiem” ${ }^{146}$. Trzeba czerpać z przeszłości i współczesności, ale zawsze $z$ umiarem i krytycznie ${ }^{147}$, gdyż zmiany zależą od akceptacji nowych wartości ${ }^{148}$. W związku $\mathrm{z}$ pojawieniem się powszechnych standardów konstytucyjnych obserwujemy przenoszenie materii konstytucyjnej na płaszczyznę ponadnarodową ${ }^{149}$. Unifikacja prawa na tym poziomie nie dokonuje się w próżni, lecz w kontekście faktycznie istniejących porządków politycznych, stąd doniosłość komparatystyki dla tej materii jest znaczna ${ }^{150}$.

145 Interpretuje się to w trzech wymiarach: makro-, medio- i mikroskali. W. Sokolewicz, Korzystanie z obcych wzorców przy projektowaniu nowej konstytucji: konieczność czy możliwość?, [w:] Zagadnienia współczesnego prawa konstytucyjnego, Gdańsk 1993, s. 34-35. Niestety, nierzadko oznacza to zaangażowanie jednego lub dwóch ekspertów, których rola sprowadza się do przedstawienia obcych rozwiązań. Czasem zagraniczne prawo staje się nie tylko przedmiotem badań, ale bronią w walce politycznej i narzędziem realizacji własnych interesów. J. Łętowski, op.cit., s. 22-24.

146 B. Banaszak, Porównawcze prawo konstytucyjne, s. 33-34.

147 R. Graczyk, Konstytucja dla Polski, Kraków-Warszawa 1997, s. $68-70$.

148 Systemy polityczne państw Europy Środkowej i Wschodniej, red. W. Sokół, M. Żmigrodzki, Lublin 2005, s. 9-10; Ch. Saunders, op.cit., s. 53-54. Trzeba pamiętać, by dokładnie zbadać instytucję pod kątem możliwości jej adaptacji. W. Sokolewicz, op.cit., s. 38-42.

149 Zasadnicze przyczyny owego fenomenu to rosnacy autorytet prawa międzynarodowego, zobowiązanie regionalne oraz przyspieszone procesy integracyjne. Ibidem, s. 22-23.

150 Ch. Delsol, Federalizm: najważniejsze sa państwa, [w:] O nowy kształt Europy. XX-wieczne koncepcje w Europie Środkowo-Wschodniej ich implikacje dla dyskusji o przyszłości Europy, Instytut Europy Środkowo-Wschodniej, Lublin 2003, s. 359. W tym ujęciu kultura konstytucyjna UE może rozwinąć się tylko wewnątrz ram organizacyjnych Unii, gdyż system nie może stworzyć warunków, na których się opiera. P.M. Huber, Democracy and Constitutional Culture of the European Union, [w:] Constitutional Cultures, s. 235, 250-252; J. Rajski, Znaczenie prawnporównawczego przygotowania międzynarodowej regulacji prawnej, Państwo i Prawo 1977, nr 12, s. 3-7, 10-11. Innym problemem jest kategoria „Konstytucji europejskiej”. J.L. Quermonne, L'Émergnce d'un droit constitutional européen, Revue Internationale de Droit Compare 2006, nr 2, s. 581-582. 
Rośnie znaczenie komparatystyki w dobie procesów integracji, harmonizacji i globalizacji stosunków międzyludzkich jako narzędzia tworzenia, stosowania i badania prawa ${ }^{151}$. Nawiązując do „owianych duchem postępu” marzeń E. Lamberta i R. Saleilles, można by pokusić się o próbę stworzenia porządku konstytucyjnego całej ludzkości dla zapewnienia pokoju, ewentualnie poprawy stosunków międzynarodowych i polepszenia poziomu ludzkiego $\dot{z}_{\text {zycia }}{ }^{152}$. Jednak tworzenie prawa na poziomie ponadnarodowym wymaga zrozumienia odrębność systemów politycznych, dzięki czemu realizowana jest funkcja integracyjna ${ }^{153}$. Potrzeba nam globalnych zasad, ram dla globalizacji, by rynek i technika nie zdominowały wartości humanitarnych ${ }^{154}$. Refleksja prowadzić może do podjęcia starań $\mathrm{w}$ przedmiocie stworzenia ponadnarodowego porządku prawnego, co wymaga kreacji pewnej metaaksjologii, prowadzącej ku „ponadnarodowym treściom o uniwersalistycznych ideałach"155.

Współcześnie problem prawa wyższego, stojącego ponad konstytucją, nie tyle dotyczy jej tworzenia, co sprowadza się do etapu jej stosowania ${ }^{156}$, czyli interpretacji. Jeśli przyjmiemy, że etos świata cywilizacji Zachodu stanowi względnie jednorodną kategorię, to efekty obowiązywania konstytucji w poszczególnych państwach tego

151 A. Kłosowska, The Nation as an Open Community, [w:] Problemy uniwersalizmu, s. 19.

152 Za namiastkę tego uznać można Kartę Narodów Zjednoczonych. U. Pruess, op.cit., s. 290.

153 M. Kikkeri, op.cit., s. 54.

154 Z. Kędzia, Constitutional Culture and Human Rights, [w:] Constitutional Cultures, s. 166.

155 R. Tokarczyk, op.cit., s. 46.

156 Dotyczy to zasadniczo sądów konstytucyjnych, ale z pewnymi zastrzeżeniami także sądownictwa powszechnego, co stanowi następstwo przyjętej zasady bezpośredniego stosowania konstytucji. J. Oniszczuk, Konstytucja RP w orzecznictwie Trybunału Konstytucyjnego na początku XXI w., Kraków 2004, s. 288-291. Zasada ta „szczególnie doniosłą rolę [...] pełni w systemach prawnych wychodzących z systemu totalitarnego". A. Preisner, Dookoła Wojtek. Jeszcze raz o bezpośrednim stosowaniu Konstytucji RP, [w:] Sześć lat Konstytucji RP. Doświadczenia i inspiracje, Warszawa 2003, s. 230. 
obszaru prowadzić będą do podobnych rezultatów ${ }^{157}$. „Interpretatorowi wolno jest korzystać $z$ wszelkich materiałów, które są relewantne dla ustalenia sensu interpretowanego przepisu"158. Zdobywa na znaczeniu teoria argumentacji, służąca uzasadnieniu przyjętego punktu widzenia wobec instytucji ponadnarodowych ${ }^{159}$. „Cała dotychczasowa praktyka orzecznicza Trybunału potwierdza prawdziwość tezy o uniwersalizacji wartości i zasad związanych z ochroną praw jednostki” ${ }^{160}$. Zdaniem niektórych do metod komparatystycznych należy sięgać jako do ultimum remedium ${ }^{161}$, według innych to raczej punkt wyjścia, porządkujący tok rozumowania, znajdujący jednak zastosowanie tylko wówczas, gdy w innym porządku dany problem został już rozwiązany ${ }^{162}$. To jednak zazwyczaj argument, a nie jednoznaczne rozstrzygnięcie ${ }^{163}$.

Zastosowanie metod porównawczych otwiera nowe możliwości dla rozwoju prawa europejskiego ${ }^{164}$. Nie chodzi tu o stworzenie jednego systemu prawa na drodze długotrwałych procesów harmonizacyjnych, lecz właśnie harmonijne funkcjonowanie obok siebie odmiennych porządków prawnych, u podstaw których leżeć będą

157 R.R. Ludwikowski, Prawo konstytucyjne porównawcze, s. 54-57.

158 L. Morawski, Zasady wykładni prawa, Toruń 2006, s. 186.

159 P. Tuleja, Podstawowe problemy, s. 227-228.

160 M. Safjan, Wstęp, [w:] Księga XX-lecia, s. VI. Polski TK posłużył się argumentami komparatystycznymi m.in. w orzeczeniu z 29 IX 1997 (K 15/97) oraz wyrokach z: 27 V 2003 r. (K 11/03); 31 V 2004 r. (K 15/04); 12 I 2005 r. (K 24/04); 11 V 2005 r. (K 18/04); 27 IV 2005 r. (P 1/05); 13 IX 2005 r. (K 38/04).

161 M. Kikkeri, op.cit., s. 309.

162 Ibidem, s. 310.

163 Ibidem, s. 273. F. Wooldridge, Basil Markensinis: Comparative Law in the Courtroom and Classroom, International and Comparative Law Quarterly 2004, Vol. 53, part 1, s. 261. Przybrać to może postać generalnego powołania się na praktykę i doktrynę albo na konkretną decyzję lud pozycję w piśmiennictwie. W Polsce dominuje odwoływanie się przede wszystkim na orzecznictwo niemiecki i francuskie. L. Morawski, op.cit., s. 191.

164 G. Alpa, Basil Markensinis: Comparative Law in the Courtroom and Classroom, International and Comparative Law Quarterly 2006, Vol. 55, part 2, s. 483. 
wspólne wartości ${ }^{165}$. Metody odgrywają kluczową rolę w działalności ETS, stanowiąc jedno $z$ narzędzi tworzenia nowych rozwiązań prawnych, ETS nazywa się nawet „laboratorium prawa porównawczego”166. „Zupełne wyabstrahowanie [prawa wspólnotowego] od prawa państw tworzących WE nie byłoby pożądane i mogłoby powodować wrażenie, że jest on systemem sztucznym i narzuconym odgórnie”. Trybunał bierze pod uwagę „ogólne zasady prawa wywiedzione ze wspólnej tradycji konstytucyjnej Państw członkowskich" ${ }^{167}$ i $z$ rzadka odwołuje się do orzeczeń sądów krajowych ${ }^{168}$. Daje to Trybunałowi pewien luz decyzyjny i nie pozwala na naruszenie zasady prymatu ${ }^{169}$.

W duchu zasady ex pluribus unum, przy pomocy metod porównawczych, Trybunał szuka rozwiązania kompromisowego, dążąc do

165 P. Giliker, Esin Orucu's The Enigma of Comparative Law: Variations on a Theme for the Twentieh-First Century and Metodology of Comparative Law, International and Comparative Law Quarterly 2006, Vol. 55, part 1, s. 243-245; J. Schwarze, Judicial Review in EC Law - Some Reflections on the Origins and the Actual Legal Situation, International and Comparative Law Quarterly 2002, Vol. 51, part 1, s. 19-28.

166 Wynika to $z$ kilku przyczyn: sędziowie pochodzą z różnych kultur prawnych, pracują w warunkach wielojęzyczności, a wiele skarg formułowanych jest w duchu kultury prawnej skarżącego. Pozwala to postawić tezę o pewnej instytucjonalizacji komparatystyki. K. Lenaerts, Interlocking Legal Orders in the European Union adn Comparative Law, International and Comparative Law Quarterly 2003, vol. 52, part 4, s. 873-876.

167 Istnieje generalny zakaz odwoływania się do prawa krajowego, poza koniecznością wykonania aktów ponadnarodowych (Norddeutsches, 39/70, ECR 004911/70). Rośnie znacznie kryteriów pozaprzepisowych. Por.: art. 6 Traktatu z Maastricht; orzeczenia ETS: Solange I ECR 1125; Nold II 4/73; ECR 0491; Bauer 44/79, ECR 3727; Johnston 222/86, ECR 1651; Unectef 222/86, ECR 2271. A. Kalisz-Prakopik, Źródła poszukiwania podstawy decyzyjnej $w$ procesie stosowania prawa wspólnotowego, [w:] Wykładnia prawa, Lublin 2006, s. 156-157. Można mówić o wykładni obustronnie przyjaznej. P. Tuleja, Podstawowe problemy, s. 229.

168 To zasadniczo krytyka określonego rozwiązania (np. ICI, 48/69, ECR 0619). Widać, że de facto ETS i tak musi brać pod uwagę prawo krajowe. M. Grzybowski, Prawo międzynarodowe i wspólnotowe jako wzorzec i przedmiot kontroli norm, [w:] Księga XX-lecia, s. 349.

169 A. Kalisz-Prakopik, op.cit., s. 143-144. 
stworzenia swoistego ius commune ${ }^{170}$. To jednocześnie środek unowocześniania prawa na drodze transponowania najnowszych osiągnięć, będący czynnikiem dynamizującym i adaptującym do nowych warunków $^{171}$. Komparatystyka wyjaśnia w pewnym sensie nie do końca jasny fenomen współczesnego prawa europejskiego. W świetle niektórych poglądów jest ona istotą czy sercem systemu, twierdzi się nawet, że porządek wspólnotowy to sui generis praktyczna realizacja założeń komparatystycznych. Tym samym komparatystyka nabiera cech źródła prawa, co niektórzy uznają za jeden z przejawów kryzysu państwa narodowego ${ }^{172}$.

Wartość komparatystyki wynika $z$ praktycznego braku granic dla badań w tym przedmiocie oraz ogólnych przesłanek porównywania: zróżnicowania i otwartości ${ }^{173}$. Pamiętajmy, że „zamykana” myśl prawna, nawet jeśli nowatorska, skazana jest na skostnienie, dogmatyzm i pozostanie w tyle w wyniku postępującego rozwoju ${ }^{174}$. $Z$ drugiej strony adaptacje i imitacje są cechą charakterystyczną współczesnego świata ${ }^{175}$ - tradycyjne tożsamości tracą na znacze-

170 K. Lenaerts, op.cit., s. 905-906. W. Czapliński, The Role of European Court of Justice in the Shaping of the Community Constitution, [w:] Constitutional Cultures, s. 253-258.

171 M. Kikkeri, op.cit., s. 278-279.

172 Co budzi większe kontrowersje na polu teorii niż praktyki. Ibidem s. $1,6,29$.

173 R. Tokarczyk, op.cit., s. 37-38.

174 Koresponduje to $\mathrm{z}$ oczekiwaniami coraz bardziej mobilnego społeczeństwa światowego. W.J. Wagner, Comparative Law: Its Methodology, s. 15, 18. Bez wartościującego porównywania nie da się stworzyć światowej kultury konstytucyjnej. R.R. Ludwikowski, Constitutional Culture, s. 79-80. Kiedy zakres kontaktów kulturowych jest ograniczony, zubożenie intelektualne staje się nieuniknione nawet wówczas, gdy bogactwo idei wydaje się niewyczerpalne. F. Ratzel, Politische Geographie, za: H. Becker, H.E. Barnes, Rozwój myśli społecznej od wiedzy ludowej do socjologii, Warszawa 1964, s. 61.

175 Nie istnieje konstytucja, przy tworzeniu której nie zaczerpnięto z dorobku myśli konstytucyjnej innych państw. Oryginalność wynika z umiejętnego połączenia rozwiązań (zasad, instytucji) zapożyczonych z konstytucji nie jednego, a kilku państw obcych. P. Sarnecki, Ustroje konstytucyjne państw współczesnych, Kraków 2005, s. 17. Jednocześnie kul- 
niu na rzecz pewnych punktów widzenia czy opinii ${ }^{176}$. „Potrzeba metody komparatystycznej jest wyraźnie widoczna w każdym studium poświęconym kulturze ludzkiej, jej instytucjom i osiągnięciom, gdyż dzisiaj skala ludzkiej egzystencji nie jest ograniczona podziałami narodowymi, ale jest szeroka jak horyzont"177. $Z$ tych (i wielu innych) powodów komparatystyka prawa konstytucyjnego to dziedzina godna uwagi wszystkich tych, którzy interesują się mechanizmami rządzenia państwem oraz organizacją i funkcjonowaniem jego instytucji ${ }^{178}$.

\section{Abstract \\ Comparative Constitutional Law. Origins, Evolutions, Possible Development}

Presented paper deals with the issue of comparative constitutional law in its historical and theoretical dimension.

It the first part author explains the essence of the problem, subject of researches and clarifies rudimentary terminology. The second part comprises synthetic prospect of historical development of comparative constitutional law (mainly contribution of outstanding and widely recognized philosophers and thinkers, but also historic events significant for the evolution) hence Classic Era, through Middle Ages, Renaissance, Age of Reason, Enlightenment, Age of Revolutions till 20th century with its totalitarian regimes, cold war and new global epoch since 1989. The last part is an attempt of obtaining general conclusions from above-described facts and views. General remarks refer to the following issues: motives and premises of development; comparative constitutional law as independent scientific discipline due to its unique methodology; evolution of the disci-

tura konstytucyjna to czynnik komplikujący proces recepcji obcych wzorców, co przesądza o przejmowaniu tylko pewnych elementów, a nie całości rozwiązań. Ch. Saunders, op.cit., s. 37-38.

176 M. Kikkeri, op.cit., s. 3.

177 Durga Das Basu, za: B. Banaszak, Porównawcze prawo konstytucyjne, s. 30.

178 Ibidem, s. 21. 
pline's subject; assumed goals and functions of researches; characteristics and difficulties of analyzed discipline; importance for academic teaching and theoretical scientific undertakings; growing meaning and significance for practise: national judicature and legislature, as well as inter - and supranational integration with harmonization of law.

General conclusion is that comparative constitutional law becomes more and more important for both academics (teaching, researches) and practitioners (draft acts, law applying) what assures thriving prospects for its future development.

Keywords: constitution, law theory, comparative law, constitutional law, methodology 